\title{
The Impact of Information Asymmetry and Client Credit on Lending Performance - Taiwan's Evidence
}

\author{
Cheng-Li Huang \\ Department of Accounting, Tamkang University, Taiwan \\ Tel: (886-2)-26-215-656Ext:3368Ｅ-mail: chengli@mail.tku.edu.tw \\ Bih-Yun Kuo \\ Department of Accounting, Shih Chien University, TamkangUniversity, Taiwan
}

Tel: (886-2)-25-381-111Ext:8215Ｅ-mail: tatskuo@mail.usc.edu.tw

Received: Feb. 28, 2014 Accepted: April 8, 2014 Published: June 1, 2014

doi:10.5296/ajfa.v6i1.5212 URL: http://dx.doi.org/10.5296/ajfa.v6i1.5212

\begin{abstract}
Using panel data from Taiwan, this paper examines the impact of information asymmetry and client credit on lending performance. Banks without huge losses from bad debts and from credit card lending are categorized as high lending performance banks, whereas banks with heavy losses from bad debts and from credit card lending are categorized as low lending performance banks. Firms are also divided into micro and small businesses (MSBs) and medium and large businesses (MLBs). Logit regression is used to identify the determinants of lending performance, including the levels of information asymmetry and client credit records. The empirical results show that: (1) MLBs with good information transparency tend to establish relationships with banks that are characterized by huge losses from bad debts and from credit card lending. (2) Small foreign firms, as well as MLBs with high profitability, cash and R\&D expenditure ratios prefer having relationships with banks with good lending performance and low credit risk. (3) MLBs and MSBs with poor credit records prefer having relationships with banks that have good lending performance and low credit risk.
\end{abstract}

Keywords: Information asymmetry, Client credit record, Lending performance, Micro and small business, Medium and large business 


\section{Introduction}

During the period from 1997 to 2008, the Asian financial crisis (1997), the credit card storm (October 2005), the subprime mortgage (August 2007) and the Fannie Mae and Freddie Mac events (July 2008) continually impacted Taiwan’s financial markets. Faced with these severe disasters, Taiwan responded by enacting its first and second financial reforms. The banking management system accompanied this change. This study uses the database managed by the Joint Credit Information Center to perform its empirical tests. We divided banks into those with or without huge losses from bad debts and heavy losses from credit card lending. We also divided firms into MSBs and MLBs. Information asymmetries with respect to the quality of the borrower's assets and the accuracy of its credit risk estimates may raise the costs of credit risk management faced by bank credit officers. The situations are somewhat different according to the scale or the transparency level of the firms involved. The more opaque a firm is, the more that it is characterized by information asymmetry (Myers and Majluf, 1984; Lummer and McConnell, 1989; Kuo and Chen, 2012). To reduce the information asymmetry, the credit officer will ask borrowers to provide audited financial statements for the last three years when handling applications for loans. However, this requirement only applies to medium and large businesses (hereafter MLBs) where the capital or amount borrowed exceeds NT\$30 million in Taiwan, and does not apply to micro and small businesses (hereafter MSBs). Therefore, in the cases where MSBs apply for loans, banks cannot check their financial position through their audited financial statements. In practice, banks can only use public information that can be accessed from the database of the Joint Credit Information Center (JCIC) to evaluate the firm's credit quality. Among the available items, the most commonly used are the "credit records of borrowers" and "credit score of the chairperson" (Kuo and Chen, 2012). From the perspective of the lending management, banks require borrowers to file audited financial statements for the last three years. Banks verify the past credit records of the firms and the credit score of the chairperson ${ }^{1}$ by checking the information provided by JCIC. Therefore, it is important for banks to understand that when they use the information supplied by JCIC they will exhibit improved lending performance.

Our purpose in this paper is to examine the impact of information asymmetry and client credit on lending performance. We extend the previous empirical work in several ways. First, for business confidentiality, prior research only includes the data from MLBs, but this study includes information from both MLBs and MSBs. We find that the loan behaviors of the two exhibit significant differences. Second, this study focuses on the business of corporate and retail finance in order to observe the impact of the factors related to lending performance. Third, the samples used also include clients who had been rejected by banks due to default or due to the fact that their credit scores were below the standard required but have now been approved for the loan process. We recognize that this approach can completely and comprehensively impact the factors influencing lending performance.

It is important to distinguish between whether the lending performance improved with the enhanced lending system and whether the improvement in lending performance was simply due to a changing operating environment. Regulators and researchers are particularly interested in the lending performance of banks and market conditions have changed 
significantly for banks as the financial system in Taiwan has undergone drastic change. Therefore, the sample period selected in this study covers a time period in which the financial marketplace has undergone serious economic and financial environmental change. During this period, the Taiwan banking industry had experienced two major financial events, one being related to corporate finance and the other to retail finance. In accordance with Financial Statistics Monthly, issued by the Central Bank of Republic of China, we classify our samples into an empirical group (with more than NT\$50 billion of accumulated bad debts written off in the five years prior to 2008, referred to as “WOBD” hereafter) and the control group ${ }^{2}$ (without NT $\$ 50$ billion in bad debts written off in the five years prior to 2008, referred to as without "WOBD" hereafter). We refer to the retail finance events as a credit card storm, and also divide the samples into an empirical group (with heavy credit card losses, hereafter referred to as "HCCL") and a control group" (without heavy credit card losses, hereafter referred to as without "HCCL”).

In Taiwan, MLBs have more flexibility in raising capital. They can borrow from banks issuing commercial paper, straight bonds or convertible bonds ${ }^{4}$. However, MSBs can only borrow from banks. Therefore, we divide the borrowers into MSBs and MLBs ${ }^{5}$ while performing the statistical analysis and carrying out the tests. We look at the impact of information asymmetry and client credit on lending performance for different sizes of firms. Furthermore, we are of the opinion that lending performance may differ by type of banks due to different risks from corporate and retail finance. Thus, we divide the banks into banks with and without heavy losses from corporate or retail finance. In a nutshell, our samples are classified as consisting of borrowers obtaining finance from banks with "WOBD" or without "WOBD" and borrowers obtaining finance from banks with "HCCL" or without "HCCL". To clarify the direct and indirect impacts of the differences in corporate and retail finance, we deliberately verify the impacts of the events individually ${ }^{6}$. All banks are simply divided into banks "with" and "without" "WOBD" and "HCCL", to reflect the level of lending performance and credit risk.

The empirical work is summarized as follows: (1) By comparing the information asymmetry and client credit ${ }^{7}$ for banks with and without "WOBD" through the use of the t-statistics test and the non-parametric Wilcoxon rank-sum test, we examine whether there are significant differences for these two types of banks. (2) By comparing the information asymmetry and client credit for banks with and without "HCCL" using the t-statistics test and the non-parametric Wilcoxon rank-sum test, we examine whether there are significant differences between these two types of banks. (3) We then segment the samples into high-performance and low-performance banks based on "WOBD”. Banks with "WOBD" are categorized as banks with low-performance and high credit risk, whereas banks without "WOBD are categorized as having high-performance and low credit risk. The logistic regression models each have a set of independent variables, including information asymmetry and client credit. Using the logit model, we investigate whether the borrowers' information asymmetry and credit records contain statistically significant differences among the banks with and without "WOBD". (4) Finally, we regard banks with "HCCL" as the banks with low-performance and high credit risk (the value of the dependent variable in the empirical 
model equals 1). By contrast, we regard banks without "HCCL" as those banks with high-performance and low credit risk (the value of the dependent variable equals 0 ). Using a logit model, we investigate whether the borrowers' information asymmetries and credit records are characterized by statistically significant differences between the banks with and those without "HCCL".

\section{Literature Review and Hypothesis Development}

\subsection{Literature Review}

Myers and Majluf (1984) indicated that firms that have been in existence for only a short time and firms that are small in size tend to be characterized by severe information asymmetry, and therefore banks are reluctant to lend to them. These firms thus face severe financing difficulties. Lummer and McConnell (1989), however, found that creditor banks are still willing to lend to borrowers with asymmetric information. This conveys a positive message to the external investors, thereby reducing the information asymmetry condition. Agarwal and Eiston (2001) indicated that firms with better operating structures would like to borrow from banks with a better credit quality in order to receive a better appraisal from the enterprise's external investors. Kuo and Chen (2012) found that the asymmetries between the borrowing customers and creditor banks may differ depending on the respective sizes of the firm. The smaller the scale of the opaque firms, the more severe is the information asymmetry. In respect of the research and switching costs, Diamond (1989), Boot and Thakor (1994) and Petersen and Rajan (1994) all found that banks will charge a lower price to reflect the reduction in research costs. When borrowers are aware of the high costs of switching banks, they will be strongly motivated to continue dealing with the original bank and will pay less attention to the changes in the bank's credit risk.

In practice, MSBs in Taiwan actually distort their financial statements through a variety of methods. Therefore, banks cannot accurately evaluate the credit risk of borrowers by examining their financial characteristics purely based on their financial statements. Therefore, within the banking industry ${ }^{8}$, in addition to the financial data, they also resort to non-financial measures to evaluate the lending case. Ruan and Jing (2003) used samples consisting of medium-sized and small and medium enterprises (SMEs) and found that by combining financial information with non-financial information they could achieve the best lending performance. Li (2005) included all the variables for credit rating in the logistic regression model and built models of financial indicators, non-financial indicators and integrated indicators. His results suggest that the most accurate prediction rate provided by these three empirical models was that of the integrated indicators' model, especially when it came to predicting the default rate of the firms, followed by the empirical model for the financial indicators. The worst model was that which only used non-financial indicators.

From the perspective of the variables used to describe lending management, Zhang et al. (2006) found that if the empirical model included a dummy variable to distinguish the borrower's industry, the model's accuracy was generally better than it was without that dummy. In the empirical tests for SME lending cases, Zeng et al. (2009) found that the financial information provided the ability to distinguish between defaulting corporations and 
normal corporations. Ruan and Jiang (2004) conducted a study on the default predictions for privately-held companies that did not file audited financial statements, and found that the credit rating, the frequency of inquiries, the rate of utilization of the amount of credit and the payment record significantly increased the ability of banks to discriminate between the various applications for loans.

\subsection{Hypothesis Development}

According to Taiwan's lending practices, when applying for bank loans, MLBs should provide audited financial statements for the past three years, and inquiries should be made through JCIC to ascertain the credit score of the chairperson and whether or not the MLBs and MSBs have had bad credit records in the past. However, as to whether these practices can enhance the lending performance and reduce the credit risk is a matter worth systematic investigation. Past empirical studies have been more focused on how the ownership type, scale and transaction frequency have impacted the banking relationship. To our knowledge, there are no studies using "WOBD” and "HCCL" that have sought to reflect bank lending performance and further explore how the information asymmetry and credit records of the borrowers impact lending performance. Based on our understanding, banks that belong to the "WOBD" category are always large in scale and banks that belong to the "HCCL" category are mixed, including large and small banks. Most of the "HCCL" banks are newly-established banks. Therefore, we refer to the following relevant articles in developing our hypotheses: "Careless Lenders and Bad Borrowers, "(Shen and Wang, 2002), "The Top One and Non-top One Financing Bank-viewpoints of lending behavior," (Chen and Lai, 2003). Berger et al. (2008) referred to the five relationships motivation theory ${ }^{9}$ which also provided us with the inspiration to predict the positive or negative directions of our results. The following four hypotheses are presented and discussed:

Hypothesis 1: Firms with more transparent information are more likely to have their loan applications approved, regardless of whether the lending performance of the bank is good or bad.

According to the past research literature, large banks have advantages with hard information; however, small banks make the most of soft information to develop new clients. Banks with "WOBD" often happen to be large banks, but "HCCL" occurs in any kind of bank. Regardless of the scale or the lending performance of the banks, they all prefer to lend to enterprises with more transparent information. The preference level may be associated with the lending type, scale and performance. ${ }^{10}$ Another possible reason why banks have a different attitude towards credit risk is the dramatic change in the competitive banking environment ${ }^{11}$ in Taiwan. Because of this, in addition to using the measures of scale and length of time in existence to reflect the level of information asymmetry, we also include a measure referred to as "before or after the approval of the policy for the establishment of new banks". To sum up, firms with more capital and assets, that have been in existence for a longer period of time, and that received their loans "before or after the approval of the policy for the establishment of new banks" will be deemed to be more transparent and with less shortage of information asymmetry. Such firms and their loan applications are welcomed by 
any kind of bank. If banks with and without "WOBD" contain significant differences in information transparency, this may indicate that banks without "WOBD" place more emphasis on information transparency. The same inferences apply to banks without "HCCL".

Hypothesis 2: It is easier for borrowers with a better credit history to establish relationships with banks, regardless of the bank's lending performance. However, whether or not a bank with low performance will reduce its contact with borrowers with a bad credit history to avoid incurring a high non-performing loan (hereafter NPL) ratio has yet to be verified. The same question applies to banks with a low performance, but that have had previous relationships with borrowers with a bad credit history. Banks with high lending performance prefer to do business with firms whose chairperson has a good credit score. This is not usually the case for banks with low lending performance.

According to the efficient frontier in portfolio theory, banks should pursue the highest rate of return within the specified risk appetite. Banks should choose the optimal client and assume a reasonable amount of credit risk, but not always look for the best borrower ${ }^{12}$. If a potential client has had a bad credit record in the past, it is right for a bank to deal with such a case in a prudent manner. Different banks deal with such cases in different ways. While some banks may abandon this type of business to avoid a high NPL ratio, other banks are attracted by a high loan spread, all of which depends on the firm's situation and lending performance. From the perspective of the borrower, as long as the borrower can raise sufficient funds to meet its debt capacity and loan interest rates are still low, then the borrower will be more willing to make contact with any kind of bank, without considering whether its lending performance is good or bad. Many studies on the Taiwan economy have shown that, unless policy-related subsidies or government relief measures are in place when banks face such loan applications from borrowers, the banks will normally ask firms to provide collateral. They will also look to see if the chairperson's credit score is above the threshold criteria, and will require a guarantee from the chairperson ${ }^{13}$.

Hypothesis 3: Borrowers that are publicly-held firms, or belong to conglomerates, and have lower industry concentration risk are more attractive to any kind of banks. Large foreign companies are commonly multi-national, have good reputations and have a need to raise funds, and so they are more willing to build a relationship with any kind of bank. Small foreign companies in Taiwan would rather choose a steady relationship with one bank that has a good lending performance within this over-banking environment.

The fifth motivation theory regarding the banking relationship discussed in Berger et al. (2008) and Kuo and Chen (2012) emphasizes the importance of the cost and benefit of monitoring. Therefore, banks with good lending performance (without "WOBD" and "HCCL") prefer having relationships with listed and OTC companies rather than with publicly-held companies. However, they would also prefer having relationships with publicly-held companies than with privately-held companies. They usually adopt the same approach with MSBs. Banks still prefer having relationships with corporations to relationships with proprietorships, partnerships or limited companies. It must also be understood that companies that are publicly-held respond differently to a bank's credit risk 
and performance, and vice versa. If a borrower is a member of a conglomerate and belongs to a high-tech or traditional industry, it needs to be asked whether this will affect the preferences of banks. It actually depends on whether the risk associated with the secured or unsecured loan related to the borrower or affiliated company exceeds the risk limits and industry concentration risk approved by the bank. According to the first and second motivation theories of banking relationships, if the borrower's predetermined scale of debt is greater than the risk appetite of the bank, then it will be rejected, and the borrower will then deal with another bank. However, it cannot be determined for certain whether the borrower will determine its banking preference according to a bank's lending performance. In this paper, we also use the marginal value generated from the empirical models of "WOBD" and "HCCL" to predict the sensitivity to lending performance. Previous studies indicate that foreign enterprises prefer relationships with foreign banks. There are no obvious conclusions as to whether foreign enterprises will change their behavior based on a foreign bank's credit risk. We will conduct empirical tests in this paper, too.

Hypothesis 4: MLBs with higher financial leverage induce higher financial risk. To fulfill their cash needs, MLBs with higher financial leverage tend to build relationships with banks regardless of the bank's lending performance. When the R\&D expenditure to total capital ratio, profitability ratio and cash ratio (measured by the ratio of cash and cash equivalents to sales) are enhanced, due to the fact that funding pressure is reduced, these MLBs will tend to build relationships with banks with low credit risk and better lending performance.

According to the viewpoints of Brick-Palia (2007), the lower financial leverage ratio, higher profitability ratio, and cash ratio will lead to lower loan spreads. This means that when banks perceive that certain clients have a low credit risk, they will be more willing to use lower interest rates to establish a relationship with them. When the clients' financial indicators, as mentioned above, reflect the expected level, banks with different lending performances will be eager to provide sufficient funds to meet their needs and to establish relationships with them. However, whether the motives for building relationships contain significant differences is still uncertain. It is thus good to show that clients are running their businesses soundly when the ratio of $R \& D$ expenditures increases, because this implies that the clients use long-term debt or funds to support their need for long-term intellectual capital. It is quite common for banks with different lending performances to be keen to meet their borrowers' financing needs, but it is worth deeply examining whether the lending motivation is different.

\section{Research Design}

\subsection{Data sources}

In Taiwan, the Joint Credit Information Center (JCIC) is a unique organization that is constantly collecting the credit information data of both individuals and enterprises. These data are collected from financial institutions on a long-term basis. The factors that influence the credit risk of enterprise borrowers are more complicated than those that influence the credit risk of individual borrowers. It is for this reason that this study focuses on examining samples of enterprise borrowers and ignores the issues of individual borrowers. Our data sources are the JCIC database established in 2007. To effectively reflect the credit records 
and credit scores of the businesses and their chairpersons, we use the population ${ }^{14}$ information on the enterprises followed by JCIC. In addition, to grasp the real picture of the lending performance in the case of firms with and without "WOBD" and "HCCL", we purposely choose the empirical period 2006-2008, a time period that followed the two important financial events referred to earlier. Our observations are focused on the new loan cases of the creditor banks ${ }^{15}$. In considering the principle of materiality and the representativeness of the data, the relationship banks should be in the list of the top 20 banks, as measured by the amounts lent to the clients.

As mentioned before, we use data from JCIC to investigate the information asymmetry and credit records of borrowers associated with banks with different lending performances. The samples used in this study consist of borrowing firms ${ }^{16}$ and their lending banks. We define the borrowing firms as MSBs (a total of 122,759 firms) where their capital and amounts borrowed are less than NT\$30 million at the same time. When either of the capital and amounts borrowed exceed NT\$30 million, we define the borrowing firms as MLBs (a total of 31,314 firms). Moreover, we divide the $\mathrm{MLBs}^{17}$ into three kinds of organizations, "Listed or over-the-counter (OTC)" (1,174 firms), "Publicly held but not listed or OTC" (966 firms) and "Privately-held with audited financial statements" (15,908 firms). ${ }^{18}$ The MSBs contained in the database of the JCIC are privately-held businesses that do not file audited financial statements with the lending banks. We further divide those businesses into "proprietorships, partnerships and limited companies” (89,295 firms) and “corporation” (33,464 firms).

We divide the borrowers' industries into the following four categories ${ }^{19}$ : electronic manufacturing industry (MSBs 2,530, MLBs 2,265), non-electronic manufacturing industry (MSBs 31,590, MLBs 10,203), wholesale and retail business (MSBs 56,794, MLBs 8,107) and other industries (mainly consisting of construction, real estate and investment industries (MSBs 31,845, MLBs 10,739). We use WOBD and HCCL to distinguish banks with high or low credit risk and operating performance. Among banks with "WOBD”, we have selected 57,948 MSBs and 10,023 MLBs. Among banks without "WOBD”, we have selected 75,619 MSBs and 5,691 MLBs. Among banks with "HCCL", we have selected 35,369 MSBs and 5,343 MLBs, and among banks without "HCCL”, we have selected 98,198 MSBs and 10,371 MLBs. There are 513 listed, 404 OTC, 133 emerging stock and 166 companies publicly-held but not included in the former three markets, giving a total of 1,210 companies used in this study.

\subsection{Operational Definition of Variables}

In order to explore whether the lending performance was impacted by information asymmetry and credit records, we grouped the factors into four dimensions and nineteen independent variables as follows: (1) Level of asymmetric information (the dimension symbol is Info). Info includes the size of the borrowers. (The sizes of MSBs and MLBs are measured by capital registered and total assets, respectively. We take the natural logarithm of capital registered and total assets as the proxy for firm size. The variables' symbols are Info_01 and Info_02, respectively.) The second variable of Info is existing length, measured by months (the variable is Info_03). The third variable of Info is when the borrowing firm was founded. 
(Before or after the deregulation to allow the establishment of new banks, the variable is Info_04. Which is a dummy variable and we denote the value as 1 when the borrower was found before 1993 otherwise the value is 0.) (2) Organization and industry type of the borrowers (the dimension symbol is Com). In MLB sample, we use two dummy variables (Com_01 and Com_02) to distinguish between listed, OTC, publicly-held and privately-held companies. If the company belongs to listed firms, the dummy variable Com_01 equal 1, otherwise the value is 0 . If the company belongs to OTC firms, the dummy variable Com_02 equal 1, otherwise the value is 0 . In the MSB sample, we use the dummy variable Com_03 to distinguish between corporations, proprietorships, partnerships and limited companies. When the MSB belongs to corporation the dummy variable equal 1, otherwise the value is 0 . We use Com_04 to distinguish whether or not the borrowing company belongs to a conglomerate if yes the dummy variable equals 1 , otherwise the value is 0 . We then use the dummy variables Com_05 and Com_06 to distinguish between foreign, state-owned or domestic companies. If the borrower belongs to foreign firms, the dummy variable Com_05 equals 1, otherwise the value is 0 . If the borrower belongs to state-owned the dummy variable Com_06 equals 1 , otherwise the value is 0 . We also use the dummy variables Com_07, Com_08, Com_09 to distinguish four kinds of industry: electronic manufacturing, non-electronic manufacturing, wholesale and retail, and others (including the construction, real estate, and investment industries). If the borrower belongs to electronic manufacturing, the dummy variable Com_07 equals 1, otherwise the value is 0 . If the borrower belongs to non-electronic manufacturing, the dummy variable Com_08 equals 1 , otherwise the value is 0 . If the borrower belongs to wholesale and retail, the dummy variable Com_09 equals 1, otherwise the value is 0. (3) Financial characteristics of the borrowers (the dimension symbol is Fin). Given that MLBs should file audited financial statements with the lending banks, in our empirical model, only MLBs are included in the dimension of financial variables. The financial variables of the borrowers include the financial leverage ratio (measured by total liabilities over total equities (\%), Fin_01), the R\&D expenditure ratio (measured by total R\&D expenses over total equities (\%), Fin_02), the profitability ratio ${ }^{20}$ (measured by EBIT over sales (\%), Fin_03), and the cash ratio (measured by cash-in-hand and cash equivalent over sales (\%), Fin_04). (4) Credit records of borrowers (The dimension symbol is Credit). This refers to whether the borrowers have faced the situation where their loans are overdue, they have defaulted, have incurred bad debts or not sufficient fund (NSF) (Credit_01). We also measure the credit rating score ${ }^{21}$ of the chairperson of the borrowing firm (the symbol is Credit_02). (The relevant magnitudes are obtained from the database of JCIC window J10.)

As mentioned before, we use with or without WOBD and with or without HCCL to measure the lending performances of the sample banks. (The dimension symbol is Status, and the two dependent variables are Status_01 and Status_02.) If the bank has written off over NT\$50 billion of bad debts within the last 5 years, the dependent dummy variable Status_01 equals 1, otherwise the dummy variable's value is 0 . The same principles and procedures are applied to HCCL. When a bank has experienced heavy credit card loss, the dependent dummy variable Status_02 equals 1, otherwise the dummy variable's value is 0 . 
Table 1. Summary of Dimensions and Variables

\begin{tabular}{|c|c|c|}
\hline Dimensions & Attributes & Variable Symbols \\
\hline Lending Performance & Dependent dummy variables & Status_01, Status_02 \\
\hline \multirow[t]{3}{*}{$\begin{array}{l}\text { Info (Level of Asymmetric } \\
\text { Information ) }\end{array}$} & Size & $\begin{array}{l}\text { Info_01 for MSBs, Info_02 } \\
\text { for MLBs }\end{array}$ \\
\hline & Existing length & Info_03 \\
\hline & $\begin{array}{l}\text { Company established before } \\
\text { or after } 1993\end{array}$ & Info_04 \\
\hline \multirow{4}{*}{$\begin{array}{l}\text { Com (Organization and } \\
\text { Industry Types of the } \\
\text { Borrowers) }\end{array}$} & Organization types & $\begin{array}{l}\text { Com_01, Com_02 for MLBs } \\
\text { Com_03 for MSBs }\end{array}$ \\
\hline & Conglomerate & Com_04 \\
\hline & Ownership & Com_05, Com_06 \\
\hline & Industry classification & Com_07,Com_08 Com_09 \\
\hline \multirow{4}{*}{$\begin{array}{l}\text { Fin (Financial } \\
\text { Characteristics of the } \\
\text { Borrowers) }\end{array}$} & Financial leverage & Fin_01 \\
\hline & $\mathrm{R} \& \mathrm{D}$ ratio & Fin_02 \\
\hline & Profitability ratio & Fin_03 \\
\hline & Cash ratio & Fin_04 \\
\hline \multirow[t]{2}{*}{$\begin{array}{l}\text { Credit (Credit Records of } \\
\text { Borrowers) }\end{array}$} & $\begin{array}{l}\text { Borrower with or without } \\
\text { bad credit record in the past }\end{array}$ & Credit_01 \\
\hline & Credit score of chairperson & Credit_02 \\
\hline
\end{tabular}

\subsection{Empirical Model}

We use logit regression to identify the determinants of lending performance. We examine how the information asymmetry and client credit records of the MSBs and MLBs impact the lending performance. According to the respective impacts of corporate finance and retail finance, we divide the credit risk and performance into two types: one is impacted by corporate finance referred to as with or without "WOBD", the other is impacted by retail finance, and is referred to as with or without "HCCL". We develop a separate model to perform the empirical testing. When using the with or without "WOBD" model, the sample borrowers are selected from the corresponding banks. If the sample firms borrow from the bank with "WOBD", the value of the dependent variable of the empirical logit model is 1 , otherwise it is $0^{22}$.

The same principles apply to with or without "HCCL" model. If the sample data are from a bank with "HCCL", the value of the dependent variable of the empirical logit model is 1 , otherwise it is 0 . This study not only considers the difference in lending performance but also considers a firm's scale, because the attributes of the MSBs and MLBs that exist are obviously different (Kuo and Chen, 2012.). Because of this, we develop two models to be applied for MSBs and MLBs. The empirical logit models are demonstrated as formulas (1) and (2). 


$$
\begin{gathered}
\left.\ln [p \text { (Status })_{\mathrm{x}} /\left(1-p(\text { Status })_{\mathrm{x}}\right)\right]=\beta_{0}+\sum_{i=1}^{m} \beta_{i} \text { Info }_{i} \\
+\sum_{j=1}^{n} \gamma_{j} \text { Com }_{j}+\sum_{l=1}^{p} \varphi_{l} \text { Credit }_{l} \\
\ln \left[p(\text { Status })_{\mathrm{z}} /\left(1-p(\text { Status })_{\mathrm{z}}\right)\right]=\beta_{0}+\sum_{i=1}^{m} \beta_{i} \text { Info }_{i} \\
+\sum_{j=1}^{n} \gamma_{j} \text { Com }_{j}+\sum_{k=1}^{o} \phi_{k} \text { Fin }_{k}+\sum_{l=1}^{p} \varphi_{l} \text { Credit }_{l}
\end{gathered}
$$

Formula (1) depicts the factors impacting the lending performance in relation to MSBs, while Formula (2) also depicts the factors impacting the lending performance in regard to MLBs. Both formulas include the dimensions of Info (level of information asymmetry), Com (organization and industry types) and Credit (credit records of borrowers), but only Formula (2) for MLBs includes the dimension of Fin (financial characteristic of borrowers). The variables are described in Table 1.

\section{Empirical Results}

We will summarize the empirical testing process over the next three subsections. First, we use the t-test and non-parametric Wilcoxon rank-sum test to verify whether the mean and median are significantly different from the perspectives of information asymmetry and client credit in banks with and without "WOBD" and "HCCL". As mentioned earlier, we divide borrowers into MSBs and MLBs and discuss each one separately. In the second and third sections, we discuss how the borrowers with their own advantage or situation build relationships with banks with different levels of credit risk and lending performance. To be specific, we regard banks with "WOBD" and "HCCL" as banks with low performance and high credit risk. Our control sample consists of banks without "WOBD" and "HCCL" and with high performance and low credit risk. We use a logit model to investigate whether the borrowers' information asymmetry and credit records contain statistically significant differences between banks with and without "WOBD" and "HCCL".

\subsection{Whether or not the Borrowers are Significantly Different}

\subsubsection{Comparisons among MSBs}

Table 2 displays the findings that banks with "WOBD" and "HCCL" prefer dealing with MSBs that are relatively large in scale. The average capital ranges between NT\$0.028 billion and NT\$0.033 billion, which is significantly higher than the controlled samples ${ }^{23}$ with between NT $\$ 0.017$ billion and NT\$0.018 billion at the 1\% level. Compared with factors for the length of time in existence (in months) and the year of establishment, we find that banks with "WOBD" prefer building relationships with MSBs characterized by longer lengths of time in existence. Banks with "HCCL" show no significant differences in this respect. 
Compared with the median of existing length, banks with "WOBD" have existed for an average of 158 months, which is significantly longer than for banks without "WOBD", for which the average is 140 months. The former generally had more clients and a more sustained borrower-lender relationship before the new bank policy to approve the establishment of new banks was introduced. The ratio is significantly higher than the latter at the $1 \%$ level. Compared to sole proprietorships, partnerships and limited companies, banks with "WOBD" engage in more lending business with corporations. The ratio is $34 \%$, which is significantly higher than the $30 \%$ for the control sample. Banks with "HCCL" prefer relationships with clients that are sole proprietorships, partnerships or limited companies than with corporate types of organizations. The ratio is $29 \%$, which is significantly lower than that for banks without "HCCL” (32\%).

As to whether MSBs that belong to conglomerates can decrease or increase the risks posed to the creditor banks with different lending performances presents a severe challenge to the banks' ability to manage credit. The empirical results show that the ratios of the clients belonging to conglomerates that build relationships with banks with "WOBD and HCCL" are $0.4 \%$ and $0.5 \%$, respectively, which are significantly higher than those for the control samples with $0.3 \%$ and $0.3 \%$ at the $1 \%$ level. This indicates that lending to companies belonging to a conglomerate does not ensure that the quality of credit is reliable (for banks with "WOBD”). If banks lend to a subsidiary of a conglomerate, they will be concerned about the efficiency or performance of any related business unit related to that conglomerate, because the whole conglomerate may be affected. Another empirical result shows that banks without "WOBD and HCCL" will tend to lend to small foreign companies, for which the ratios are $0.3 \%$ and $0.3 \%$, significantly higher than those for the control samples of $0.1 \%$ and $0.1 \%$. The implication is that small foreign companies pose less credit risk, and so it is reasonable to promote business lending to them. Lending in the cases of banks with "WOBD and HCCL", which carry poor credit records are up to $22 \%$ and $26 \%$, which were significantly higher than the control samples of $17 \%$ and $17 \%$. This explains why these banks have a higher credit risk. When comparing from the aspect of the credit score of the chairperson, the empirical results are quite similar in that cases of lending by banks with "WOBD and HCCL" have an average credit ratings of 509.72 and 473.63, respectively, which is significantly lower than the 541.45 and 548.28 for the control samples.

\subsubsection{Comparison among MLBs}

From the results of Table 2, we found that the lending behaviors of banks with different lending performances were quite similar, including in terms of asset size, the length of time in existence and the company's year of establishment. This means that banks with "WOBD and HCCL” prefer building relationships with large-scale companies, whose average total assets are between NT\$1,536 million and NT\$2,481 million. These averages are significantly larger than those for the control samples where the average total assets were between NT\$526 and NT\$495 million at the 1\% level. From the perspective of the length of time in existence and the company's year of establishment in the case of the MLBs, banks with "HCCL" were significantly smaller than banks without "HCCL" at the 5\% level. Variables related to banks with "WOBD" were significantly larger those for than banks without "WOBD" at the $1 \%$ 
level. From the perspective of the type of organization, banks with "WOBD and HCCL" preferred building relationships with publicly-held or OTC firms (8\% and 12\%), which were significantly higher than those for the control samples (4\% and $4 \%$ ) at the $1 \%$ level. For clients belonging to conglomerates (13\% and 19\%), the ratios were significantly higher than for the control samples (7\% and 7\%) at the $1 \%$ level.

As to the comparison of the financial variables, we found that clients of banks with "WOBD" had a significantly higher financial leverage ratio (the mean was 246.13\%) than the control samples (230.44\%) at the $1 \%$ level. The median rose to $200.59 \%$. This seems to indicate that banks with "WOBD” accept lending business from MLBs with a higher financial leverage ratio which will lead to higher credit risk. The means of the MLBs of banks with "HCCL" are $0.98 \%$ and $5.31 \%$ based on the ratios of $R \& D$ expenditures and profitability, which are significantly higher than the corresponding $0.58 \%$ and $4.08 \%$ for the control samples at the $1 \%$ level. The cash ratio of $9.89 \%$ is significantly lower than the $11.83 \%$ for the control samples at the same level. This reveals that when compared to the R\&D expenditures and profitability ratios, the cash ratio can better reflect the quality of credit risk. From the perspective of the past credit records of banks with different lending performances, there is no significant difference between the experimental and control samples. The credit score of the chairperson of MLBs of banks with "WOBD and HCCL" (the average scores are 644.32 and 628.96, and the medians are 656 and 639) is significantly lower than for the control samples (the average scores are 657.81 and 659.91, and the medians are 673 and 674) at the $1 \%$ level. This seems to reflect the fact that banks with low lending performance ignore the fact that the credit score of the chairperson can serve as a signal of credit risk.

\subsection{The Logit Model Distinguished by with or without “WOBD” Events}

In this study, we measure a bank's lending performance according to whether it encounters the events of "WOBD" and "HCCL." Therefore, we divide the relationship banks into those with "WOBD" and those with "HCCL." For purposes of comparison, we also choose the clients of banks without "WOBD" and "HCCL" as the control samples ${ }^{24}$. With respect to the borrowers, "WOBD” results from corporate financial failure and impacts the financing needs directly, while "HCCL" results from retail financing failure, which only impacts financing needs indirectly. However, each circumstance will increase the credit risk of banks. If bad experiences accrue at the same time, the credit risk will increase dramatically. To clarify the different responses from the direct and indirect impacts, we test both events individually, and simply divide the banks into those with or without "WOBD" or "HCCL". Banks with "WOBD" and "HCCL" are characterized by high credit risk and low lending performance. Banks without "WOBD" and "HCCL" are characterized by low credit risk and high lending performance. To avoid confused perceptions of lending behavior, we exclude the samples of borrowers who maintain relationships with banks with both high and low credit risks. 


\section{Macrothink}

Asian Journal of Finance \& Accounting

ISSN 1946-052X

2014, Vol. 6, No. 1

Table 2. Comparison of MSBs and MLBs from Different Perspectives

\begin{tabular}{|c|c|c|c|c|c|c|c|c|c|c|}
\hline \multirow{4}{*}{ 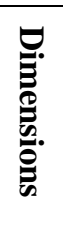 } & \multirow{3}{*}{\multicolumn{2}{|c|}{ Impact Variables }} & \multicolumn{4}{|c|}{ Borrowers: MSBs } & \multicolumn{4}{|c|}{ Borrowers: MLBs } \\
\hline & & & \multicolumn{2}{|c|}{ "WOBD" Events } & \multicolumn{2}{|c|}{ "HCCL” Events } & \multicolumn{2}{|c|}{ “WOBD” Events } & \multicolumn{2}{|c|}{ "HCCL” Events } \\
\hline & & & $\mathrm{Y}$ & $\mathrm{N}$ & $\mathrm{Y}$ & $\mathrm{N}$ & $\mathrm{Y}$ & $\mathrm{N}$ & Y & $\mathrm{N}$ \\
\hline & Samples & & 57,948 & 75,619 & 35,369 & 98,198 & 10,023 & 5,691 & 5,343 & 10,371 \\
\hline \multirow{6}{*}{$\Xi$} & \multirow{2}{*}{$\begin{array}{c}\text { Info_01 or } \\
\text { Info_02 }\end{array}$} & M & $0.28^{* * *}$ & 0.17 & $0.33^{* * *}$ & 0.18 & 5.26 & $24.81^{* * *}$ & 4.95 & 4.95 \\
\hline & & $\mathrm{m}$ & $0.05^{* * *}$ & 0.05 & $0.05^{* * *}$ & 0.05 & 1.33 & $2.37^{* * *}$ & 1.4 & 1.4 \\
\hline & \multirow{2}{*}{ Info_03 } & $\mathrm{M}$ & $172.99^{* * *}$ & 156.57 & $152^{* * *}$ & 167.98 & 204.88 & $217.52^{* *}$ & 222.95 & 222.95 \\
\hline & & $\mathrm{m}$ & $158^{* * *}$ & 140 & $134^{* * *}$ & 154 & 189 & $199^{* * *}$ & 209 & 209 \\
\hline & \multirow{2}{*}{ Info_04 } & $\mathrm{M}$ & $0.46^{* * *}$ & 0.4 & $0.37^{* * *}$ & 0.44 & 0.56 & $0.6^{* * *}$ & 0.63 & 0.63 \\
\hline & & $\mathrm{m}$ & $0^{* * * *}$ & 0 & $0^{* * *}$ & 0 & 1 & $1^{* * *}$ & 1 & 1 \\
\hline \multirow{8}{*}{ 青 } & \multirow{2}{*}{ Fin_01 } & M & - & - & - & - & 230.44 & $236.36^{* *}$ & 242.55 & 242.55 \\
\hline & & $\mathrm{m}$ & - & - & - & - & 179.07 & 194.23 & 192.10 & 192.10 \\
\hline & \multirow{2}{*}{ Fin_02 } & M & - & - & - & - & 0.69 & $0.98^{* * *}$ & 0.58 & 0.58 \\
\hline & & $\mathrm{m}$ & - & - & - & - & 0 & $0^{* * *}$ & 0 & 0 \\
\hline & \multirow{2}{*}{ Fin_03 } & $\mathrm{M}$ & - & - & - & - & 4.59 & $5.31^{* * *}$ & 4.08 & 4.08 \\
\hline & & $\mathrm{m}$ & - & - & - & - & 2.84 & $3.24^{* * *}$ & 2.68 & 2.68 \\
\hline & \multirow{2}{*}{ Fin_04 } & $\mathrm{M}$ & - & - & - & - & 13.46 & $9.89 * * *$ & 11.83 & 11.83 \\
\hline & & $\mathrm{m}$ & - & - & - & - & 6.97 & $5.39^{* * *}$ & 6.16 & 6.16 \\
\hline \multirow{4}{*}{ ?: } & \multirow{2}{*}{ Credit_01 } & M & $0.22^{* * *}$ & 0.17 & $0.26^{* * *}$ & 0.17 & 0.004 & 0.004 & 0.003 & 0.003 \\
\hline & & $\mathrm{m}$ & $0^{* * *}$ & 0 & $0^{* * *}$ & 0 & 0 & 0 & 0 & 0 \\
\hline & \multirow{2}{*}{ Credit_02 } & $\mathrm{M}$ & $509.72^{* * *}$ & 541.45 & $473.63^{* * *}$ & 548.28 & 657.81 & $628.96^{* * *}$ & 659.91 & 659.91 \\
\hline & & $\mathrm{m}$ & $624^{* * *}$ & 640 & $580^{* * *}$ & 647 & 673 & $639^{* * *}$ & 674 & 674 \\
\hline
\end{tabular}

Note 1: The symbols $\mathrm{Y}$ and $\mathrm{N}$ indicate that the events occur and do not occur. The mean $(\mathrm{M})$ and ymedian $(\mathrm{m})$ of the variables in each dimension are examined by $\mathrm{t}$ and the Wilcoxon rank sum tests. ${ }^{* * *}$, ** and $*$ indicate significance at the $0.01,0.05$ and 0.1 levels, respectively.

Note 2: For simplicity, Table 2 does not present the descriptive statistics of the dummy variable Com_01-Com_09 in dimension Com.

The empirical findings in Table 3 indicate that enterprises featured by "large size and a long period of time in existence" have good information transparency and tend to $^{25}$ build relationships with banks with "WOBD". The coefficients of the regression model for MSBs are 0.18 and 0.001 , and for MLBs are 0.30 and 0.009 , respectively. Although "large size and a long period of time in existence" are symbols of good information transparency, they are not an assurance of less operating risk. Therefore banks should deal with loan applications more prudently, especially during times of recession. If banks do not have a sound risk limiting system, nor a facilities ratings system to manage industry concentration risk and they blindly adopt the lending business practices of borrowers with highly transparent information, they may suffer considerable losses in the near future. This phenomenon has become even more severe due to the lending market facing intense competition after the announcement of 
the policy to approve the establishment of new banks. Banks with high credit risk purposely expand and extend their conditions and criteria of lending to attract new and opaque companies (the coefficient is -0.04). From the perspective of the organization type and industry of the enterprise, compared to private enterprises, foreign companies prefer establishing relationship with low credit risk bank (the coefficient is -1.02). Compared to sole proprietorships, partnerships and limited companies, it seems that corporations prefer building relationships with low credit risk banks (the coefficient is -0.04). Compared to the construction and real estate industry, it seems that firms within the electronic and the non-electronic manufacturing industries and wholesale industries (the coefficients are 0.11 , 0.06 and 0.24, respectively) prefer to build relationships with high credit risk bank. Compared to privately-held companies, it seems that publicly-held companies (the coefficient is 0.28 , and the odds ratio is 1.32) prefer to build relationships with high credit risk banks. Compared to publicly-held companies, it seems that listed and OTC firms (the coefficient is 0.33, and the odds ratio is 1.4) prefer to establish relationships with high credit risk banks. This implies that such banks do not have a comprehensive understanding of the industrial environment. Although higher public offerings will accompany those companies with more transparency, they do not guarantee better profitability. Hence, it is beneficial to remain alert when dealing with clients in such situations to reduce risk and enhance performance.

From the perspective of the borrower's financial variables, large clients with high profitability ratios, cash ratios and $R \& D$ expenditure ratios prefer building relationships with banks with low credit risk (the coefficients are $-0.004,-0.009$ and -0.025 , respectively). Only companies with high financial leverage ratios select or are accepted by banks with high credit risk (the coefficient is 0.0005). However, it is not worthwhile adopting such lending business at the expense of increasing credit risk. Both MSBs and MLBs with poor credit records prefer building relationships with low credit risk banks (the coefficient in large companies is -2.12, which is significant at the $1 \%$ level). If the credit score of the borrower's chairperson is increasing, it will tend to access finance from low credit risk banks. The coefficients of the MSBs and MLBs are -0.0006 and -0.0035 , respectively. This perhaps reflects the fact that banks with low credit risk have low liquidity risk. Therefore, they should be concerned about the prospects of such a company and only with caution agree to meet the financing demands of the company. It is critical to only proceed if the bank receives assurances from the chairperson or directors or supervisors. 
Table 3. Using Logit Model to Distinguish Credit Risk by “WOBD” Event

\begin{tabular}{|c|c|c|c|c|c|}
\hline Dimensions & Status_01 & MSBs & Odd Ratio & MLBs & Odd Ratio \\
\hline & intercept & $0.283^{* * *}$ & & $2.2194 * * *$ & \\
\hline \multirow{4}{*}{ Info } & Info_01 & $0.1801^{* * *}$ & 1.197 & & \\
\hline & Info_02 & & & $0.2966 * * *$ & 1.345 \\
\hline & Info_03 & $0.00105^{* * *}$ & 1.001 & $0.0009^{* * *}$ & 1.001 \\
\hline & Info_04 & $-0.0417^{* *}$ & 0.959 & $0.1412^{* *}$ & 1.152 \\
\hline \multirow{9}{*}{ Com } & Com_01 & & & $0.2787^{* *}$ & 1.321 \\
\hline & Com_02 & & & $0.3326^{* * *}$ & 1.395 \\
\hline & Com_03 & $-0.0429 * * *$ & 0.958 & & \\
\hline & Com_04 & -0.1043 & 0.901 & -0.0962 & 0.908 \\
\hline & Com_05 & $-1.0232 * * *$ & 0.359 & -0.9261 & 0.396 \\
\hline & Com_06 & 0.0492 & 1.05 & 8.5285 & $>999.999$ \\
\hline & Com_07 & $0.1149 * * *$ & 1.122 & 0.0115 & 1.012 \\
\hline & Com_08 & $0.0553^{* * *}$ & 1.057 & 0.0737 & 1.077 \\
\hline & Com_09 & $0.2391 * * *$ & 1.27 & $0.4329 * * *$ & 1.542 \\
\hline \multirow{4}{*}{ Fin } & Fin_01 & & & $0.00054 * * *$ & 1.001 \\
\hline & Fin_02 & & & $-0.0247 * * *$ & 0.976 \\
\hline & Fin_03 & & & $-0.00422 * * *$ & 0.996 \\
\hline & Fin_04 & & & $-0.00934^{* * *}$ & 0.991 \\
\hline \multirow{2}{*}{ Credit } & Credit_01 & -0.00755 & 0.992 & $-2.1188^{* * *}$ & 0.12 \\
\hline & Credit_02 & $-0.00056 * * *$ & 0.999 & $-0.00348 * * *$ & 0.997 \\
\hline
\end{tabular}

Note $1: * * *, * *$ and $*$ denote significance at the $0.01,0.05$ and 0.1 levels, respectively.

Note 2: The Likelihood Ratio (Chi-square value) of the Logit Model for MSBs is 2,348.45, and the Likelihood Ratio (Chi-square value) of the Logit Model for MLBs is 936.47, which shows that the model had good fit at the $1 \%$ level.

\subsection{The Logit Model Distinguished by with or without "HCCL" Events}

"HCCL" arises due to the failure of the retail financing business. Although the clients differ from the clients in the case of corporate finance, "HCCL" is still an indicator of credit risk management. When banks experience "HCCL" and maintain high NPL ratios, they still have the capacity to finance clients with information asymmetry and poor credit. This is worth carefully exploring. In this section we focus on investigating how "HCCL" banks with high credit risk affect the borrowers' funding needs.

The empirical findings in Table 4 show that both MSBs and MLBs that are larger scale prefer building relationships with banks that are categorized as being with "HCCL" (the coefficients are 0.066 and 0.397 , respectively, and the odds ratio of the latter reaches as high as 1.487). Companies that have been in existence for a shorter period of time are more opaque, and 
therefore creditors need to be careful to grasp the overall picture of potential operating risk. Banks with "HCCL" are more willing to deal with such enterprises (the coefficients of MSBs and MLBs are -0.0004 and -0.0011, respectively). Banks with "HCCL" are more eager to deal with MSBs established after the policy to approve the establishment of new banks was introduced (the coefficient is -0.193). There is no doubt that the NPL ratio remains high. Banks with "HCCL" do not wish to deal with corporations among the MSBs (the coefficient compared to the sole proprietorships, partnerships, and limited companies is -0.181). This is similar to banks with "WOBD" as mentioned in the previous section. Only the MSBs belonging to a conglomerate (the coefficient is 0.467 , and the odds ratio is 1.595 ) can ignore the credit risk of its lending banks, for the conglomerate can back up its member businesses internally with funding needs. However, the conglomerates with poor internal controls may deliberately deal with banks with high credit risk, act in collusion and empty the assets of the enterprise on purpose. Compared to the privately-held firms, small foreign enterprises are more likely to refuse to deal with banks with "HCCL" (the coefficient is -0.899). Most of the "HCCL" banks are newly established. It is understood that they actively promote retail finance and intend to expand the market of privately-held companies. For this reason, it is understood that more risk management is needed.

The empirical results also indicate that in comparing listed companies with publicly-held companies and publicly-held companies with privately-held companies, the former prefer building relationships with banks with "HCCL" (the coefficients are 0.391 and 0.563 , and the odd ratios are 1.48 and 1.71, respectively). There are no differences in ownership types, regardless of their being stated-owned or privately-owned or even foreign banks. MLBs with high cash and R\&D expenditure ratios regularly deal with banks without "HCCL" (the coefficients are -0.007 and -0.031). These findings fully reflect the fact that banks with "WOBD and HCCL" have a shortage of knowledge in terms of analyzing financial statements. MLBs with high financial leverage regularly and positively deal with "HCCL" banks (the coefficient is 0.0003). This implies that those banks that perform poorly in the management of retail finance will perform poorly in the management of corporate finance, too. MLBs with high or low profitability keep maintain the same attitude in dealing with banks with or without "HCCL". Companies with poor credit records, regardless of whether they are MSBs or MLBs, will tend to build relationships with low credit risk banks without "HCCL". Compared to MSBs, the intentions of MLBs are 4 times higher (the coefficients are -0.696 and -2.682, respectively, and the odds ratios are about 7 times). When the chairperson's credit rating improves, the borrower will tend to access finance from low credit risk banks without "HCCL" (the coefficients are -0.002 and -0.006 , respectively). This also indicates that if a borrower takes action to improve its credit rating, banks without "HCCL" are sufficiently flexible to accept such loan applications. To sum up, "HCCL" banks are not only short on knowledge as to how to analyze the borrower's financial statements, but are also inflexible in terms of adjusting their lending policy to accept clients with a poor credit record. This can result in the loss of potential clients with improved credit ratings. 
Table 4. Using Logit Model to Distinguish Credit Risk by "HCCL” Events

\begin{tabular}{|c|c|c|c|c|c|}
\hline Dimensions & Status_02 & MSBs & $\begin{array}{l}\text { Odds } \\
\text { Ratio }\end{array}$ & MLBs & $\begin{array}{l}\text { Odds } \\
\text { Ratio }\end{array}$ \\
\hline & intercept & $0.7085 * * *$ & & $3.0584 * * *$ & \\
\hline \multirow[t]{4}{*}{ Info } & Info_01 & $0.0657 * * *$ & 1.068 & & \\
\hline & Info_02 & & & $0.3966 * * *$ & 1.487 \\
\hline & Info_03 & $-0.00042 * * *$ & 1 & $-0.00114 * * *$ & 0.999 \\
\hline & Info_04 & $-0.1927 * * *$ & 0.825 & 0.0523 & 1.054 \\
\hline \multirow{9}{*}{ Com } & Com_01 & & & $0.3908 * * *$ & 1.478 \\
\hline & Com_02 & & & $0.5363 * * *$ & 1.71 \\
\hline & Com_03 & $-0.181 * * *$ & 0.834 & & \\
\hline & Com_04 & $0.4668 * * *$ & 1.595 & 0.082 & 1.086 \\
\hline & Com_05 & $-0.8986 * * *$ & 0.407 & 0.0633 & 1.065 \\
\hline & Com_06 & 0.5598 & 1.75 & 9.6137 & $>999.999$ \\
\hline & Com_07 & $0.1518 * * *$ & 1.164 & 0.0798 & 1.083 \\
\hline & Com_08 & $-0.0451 * *$ & 0.956 & -0.0616 & 0.94 \\
\hline & Com_09 & 0.00679 & 1.007 & $0.1427 * * *$ & 1.153 \\
\hline \multirow{4}{*}{ Fin } & FIN_01 & & & $0.00029 * * *$ & 1 \\
\hline & FIN_02 & & & $-0.0307 * * *$ & 0.97 \\
\hline & FIN_03 & & & -0.00116 & 0.999 \\
\hline & FIN_04 & & & $-0.00706 * * *$ & 0.993 \\
\hline \multirow[b]{2}{*}{ Credit } & Credit_01 & $-0.6958 * * *$ & 0.499 & $-2.6842 * * *$ & 0.068 \\
\hline & Credit_02 & $-0.00223 * * *$ & 0.998 & $-0.00595 * * *$ & 0.994 \\
\hline
\end{tabular}

Note $1: * * *, * *$ and $*$ denote significance at the $0.01,0.05$ and 0.1 levels, respectively.

Note 2: The Likelihood Ratio (Chi-square value) of the Logit Model for MSBs is 2,878.19, and the Likelihood Ratio (Chi-square value) of the Logit Model for MLBs is 1,704.57, which reflects good model fit at the $1 \%$ level.

\section{Conclusions}

Using logit regression models, we explored whether banks with different lending performances placed different levels of emphasis on information asymmetry and client credit records. The empirical results show that: (1) MLBs with good information transparency tend to establish relationships with "WORD" and "HCCL" banks. These results reveal that borrowers characterized by good information transparency and large size tend to establish multiple relationships, regardless of whether the banks are characterized by high or low lending performance. Banks with "HCCL" tend to build relationships with borrowers that have been in existence for short periods of time, especially following the approval of the policy for the establishment of new banks. This indicates that over-banking exists in Taiwan. (2) Small foreign firms, as well as MLBs with high profitability ratios, cash ratios and R\&D expenditure ratios prefer building relationships with high lending performance and low credit risk banks. Owing to the problem of over-banking, the borrowers with high financial leverage ratios are still adopted by banks with low lending performance. (3) MSBs and MLBs with 
poor credit records prefer having relationships with banks with high lending performance and low credit risk. Moreover, in the case of where the chairperson's credit score is increased, it is found that banks with high lending performance are sufficiently flexible in taking into consideration soft information instead of just hard information. This creates a policy that is not only beneficial to the lender, but is also beneficial to the borrowers.

According to a survey from Taiwan, it was found that the MSBs that received loans from banks accounted for only 4\% of the total in 2006 and the amount financed was less than one million. Therefore, if the Accounting Association in Taiwan makes an effort to introduce the IFRS for SMEs to these MSBs and helps them prepare financial statements periodically, it will help reduce the likelihood of information asymmetry and the probability of such firms receiving loans from banks. Moreover, banks can enhance their lending performance by expanding their lending activities to thousands of MSBs. It is really a four-way win policy for the government, banks, accounting associations and firms, and it is worth coordinating related units to introduce these improved policies or regulations.

Although the empirical results indicate that client credit records are a very important source of information for lending activity, it is recognized that many clients cannot provide all the needed financial statements. This study confirms the prior research findings that integrated financial and non-financial indicators in the prediction defaulting model will result more accurate prediction rates. Moreover, we suggest the future research can refer to the method presented by Jacobson and Roszbach (2003), using Bivariate probit regression model to solve the sampling selection bias to explore what factors significantly impact the lending performance of banks and default of borrowers and how it work.

\section{Notes}

1. It is a requirement of the banking association that a lending bank check a firm's credit record in the JCIC before approving each loan case. In this paper, we define "bad credit record in the past" as referring to those firms that have a record of default, not sufficient funds (NSF) or bad debts. Although checking the credit score records of the chairperson is not essential, most banks do so. Banks especially do this in the case of borrowers with a poor credit record and a relatively high risk of default. Banks will ask for collateral and the chairperson's credit score above a certain threshold, even with a guarantee. Therefore, the information regarding the "credit score of the chairperson" released by the JCIC is essential in practice.

2. According to Financial Statistics Monthly, issued by the Central Bank, at the end of 2008 there were 7 banks that were identified as having written off bad debts amounting to over NT\$50 billion. However, we cannot provide detailed information about these banks or financial holding companies, for confidentiality reasons. These 7 banks are regarded as the control sample.

3. According to the report on the debt negotiation in retail finance issued by the Bankers' Association, there are 8 banks that are characterized by heavy losses from credit card loans. 
However, we cannot provide detailed information about these banks or financial holding companies, for confidentiality reasons. These 8 banks are regarded as the control sample.

4. In Taiwan, publicly-held companies are permitted to issue straight bonds, but only listed and over-the-counter (OTC) companies are allowed to issue convertible bonds.

5. Concerning to the operating definitions of MSBs and MLBs, please refer to Sections 3.1 and 3.2.

6. If the bank's top executives are unable to examine the failure of operating strategies in corporate finance in depth, and they rush to expand their credit card and cash card-based "retail finance business", this will result in their incurring huge losses for the second time. When the issuing bank and the cardholder lack risk awareness and an appropriate management mechanism, it will be more of a challenge for them to deal with both the direct and indirect impacts of credit risk.

7. In this study, "Client credit" includes the aforementioned credit history, the type of organization, the industry category and financial attributes (this dimension is used only in the MLBs-related empirical model).

8. As mentioned earlier, this study focuses on exploring whether banks that focus more attention on their loan policy will be rewarded with a better lending performance. The loan policy mentioned here includes collecting relevant financial information (i.e., financial attributes) and non-financial information (especially public credit history).

9. According to Berger et al. (2008) and Kuo and Chen (2010), the reason for the multiple lender-borrower relationships is contained in five motives: (1) A bank cannot supply all funds needed, but dealing with numbers of banks can solve the problem. (2) The borrower can solve the hold-up problem through multiple banking relationships. (3) The borrower wants to protect itself against a premature withdrawal of credit or other services due to the distress of their banking relationship so that they can maintain their own creditworthiness. (4) To avoid the loss of relationship banking due to the tightness of credit policy. (5) To focus on the costs and benefits of the Bank in relation to supervision.

10. These factors may affect the bank's loanable funds and some factors may be subject to restrictions in the laws and regulations and not just result from information transparency. For example, the amount that banks lend to individual enterprises must not exceed $5 \%$ of its net worth even if the enterprise has good credit quality and information transparency, unless it is for syndicated loans.

11. For example, after the policy for approving the establishment of new private banks was approved, there resulted the phenomenon of over-banking. This caused banks to relax credit conditions to attract customers. After 2008, the financial tsunami and the European debt crisis resulted in banks adopting a more conservative attitude in dealing with loan applications.

12. Because selecting the best client can only earn the bank normal returns and it is unable to generate excess returns. 
13. Hypothesis 2 aims at exploring how borrowers with different credit records build banking relationships with banks possessing different levels of credit risk. The prior research literature discussed "the relationship between the borrower's financial performance and banking relationships.” It also explored "the relationship between the borrower's credit quality and the operating performance of banks (especially foreign and domestic banks or state-owned or private banks)." There is no mention of the issue of how borrowers with different credit records build banking relationships with banks possessing different degrees of credit risk. Therefore, we provide the inference based on the principles of lending management and portfolio theory.

14. Taiwan approved the registration of more than 1.5 million enterprises, but only about 140,000 enterprises borrowed from banks. Because of this, the population here is composed of the data contained in the credit database of the Joint Credit Center in 2007, which did not indicate the total numbers of enterprises registered throughout the country. Moreover, the results from 2006-2008 are quite similar, so that we only discuss the results for 2007.

15. In lending practice, banks generally require enterprises that apply for loans to provide financial statements for the past three years. Therefore, if the empirical period periods described by creditor banks extend from 2006 to 2008, then the corresponding empirical periods for the borrowers extend from 2003 to 2008.

16. In this study, the sample did not exclude "policy loans". We found that the state-owned banks are the most willing to promote loans with the government. Since the sample characterized by this attribute still accounts for less than $1 \%$ of the overall sample, it does not affect the reliability and validity of the empirical results.

17. This classification method is based on the first edition of the Joint Credit Information Center's credit scoring models. The Corporation Act was revised in 2001. At that time, the competent authority, based on the principles of corporate autonomy, deleted the regulation that capital exceed NT\$500 million. In this study, we still include this category of information content.

18. According to the classification criteria of MLBs, either a capital or a borrowing amount of more than NT\$30 million will qualify. In our populations, there are 13,266 observations that belong to MLBs. These are categorized as "non-publicly held \& no financial statements," and therefore we exclude them form our empirical test, because of "no financial statements, no financial variables.”

19. It is mentioned here that the industry classification of borrowers can also be used in the criteria under the Taiwan Stock Exchange and the OTC Exchange Center. Due to the significance of and differences in the information, the content is not obvious. We thus use the classification criteria of the credit-scoring models provided by the Joint Credit Information Center. 
20. In addition to the four variables above, we also considered the rate of return on total assets and the debt ratio during the process of developing our empirical models. However, due to the possibility of multicollinearity with the profitability ratio and financial leverage ratio, we finally abandoned them.

21. Brick-Palia (2007) regarded the collateral provided by the company as inside collateral, and the collateral or personal guarantee provided by top management as outside collateral. In this study, we use the borrowing firms as our sample, and because each firm has a number of secured and unsecured loans, we do not use the method of Brick-Palia, which took the variable of collateral into consideration. Instead, we use the credit record of the enterprise in the past (Credit_01) and the credit score of the chairperson (Credit_02).

22. The value of the dependent variable only has the meaning of "classification", and has absolutely nothing to do with the numerical value.

23. The control samples refer to MSBs that build relationships with banks without "WOBD" and "HCCL".

24. To be specific, for the borrowers of banks with "WOBD", the control samples are defined as the borrowers of banks without "WOBD". When the research object is the borrowers of banks with "HCCL", the control samples are defined as the borrowers of banks without "HCCL".

25. According to the dependent variables in formulas (1) and (2), which refer to the ratios of event occurrences relative to their not occurring, we take the natural logarithms. For simplicity, we simply use tendencies and preferences in favor of measuring the variables, and hope it will not result in a misunderstanding on the part of the reader.

\section{References}

Agarwal, R., \& Eiston, J. A. (2001), Bank-Firm Relationships, Financing and Firm Performance in Germany. Economics Letters, 72, 225-237. http://dx.doi.org/10.1016/S0165-1765(01)00427-X

Berger, A. N., Klapper, L. F., Peria, M. S. M., \& Zaidi, R. (2008). Bank ownership type and banking relationships. Journal of Financial Intermediation, 17(1), 37-62. http://dx.doi.org/10.1016/j.jfi.2006.11.001

Berger, A. N., \& Thakor A. V. (1994). Moral Hazard and Secured Lending in an Infinitely Repeated Credit Market Game. International Economic Review, 35(4), 899-920. http://www.jstor.org/stable/2527003

Brick, I. E., \& D. Palia (2007). Evidence of jointness in terms of relationship lending. Journal of Financial Intermediation, 16(3), 452-476. http://dx.doi.org/10.1016/j.jfi.2007.01.001

Diamond, D. W. (1989). Reputation Acquisition in Debt Markets. Journal of Political Economy, 97(4), 828-862. http://www.jstor.org/stable/1832193

Jacobson, T. \& K. Roszbach (2003). Bank Lending Policy, Credit Scoring and Value-at-risk, 
Journal of Banking and Finance, 27(4), 615-633. http://dx.doi.org/10.1016/S0378-4266(01)00254-0

Kuo, B.Y., \& Chen, J.T. (2012). Bank ownership types and multiple relationships with corporate clients. Academia Economic Papers, 40(1), 111-161.

Li, M. Y. (2005). Building and verification of the credit scoring model of banks-Evidence from Taiwan’s SMEs, Master's Thesis, Graduate school of Finance, Shin Hsin University.

Lummer, S. L. \& McConnell, J. J. (1989). Further Evidence on the Bank Lending Process and the Capital-Market Response to Bank Loan Agreements. Journal of Financial Economics, 25(1), 99-122. http://dx.doi.org/10.1016/0304-405X(89)90098-6

Myers, S. C., \& Majluf, N. (1984). Corporate Financing and Investment Decisions When Firms Have Information Investors Do Not Have. Journal of Financial Economics, 13, 187-221. http://ssrn.com/abstract=1505916

Petersen, M., \& Rajan, R.(1994). The Benefits of Lending Relationships: Evidence from Small Business Data. Journal of Finance, 49(1), 3-37. http://www.jstor.org/stable/2329133

Ruan, Z. Z., \& Jing, Y. K. (2003). A study of credit scoring on SMEs. Credit Information, Monthly, Oct. Joint Credit Information Center.

Ruan, Z. Z., \& Jiang, J. C. (2004). Building and verification of the Credit scoring model on Taiwan enterprises. Credit Information Monthly, June. Joint Credit Information Center.

Shen, C. H., \& Wang, J. A. (2005). Does Bank Relationship Matter for a Firm Investment and Financial Constraints? - The Case of Taiwan. Pacific-Basin Finance Journal, 13, 163 184. http://dx.doi.org/10.1016/j.pacfin.2004.07.004

Zhang, D. C., Lin, Y. L. \& Huang J. K. ( 2006). Industrial differences and enterprise financial crisis model. Taiwan Banking and Finance Quarterly, 7(4), 1-26.

Zeng, X. H., Sun, Y.Z., \& Wu, R. S. (2009). An analysis of corporate crisis warning-A logit modeling empirical test with financial indicators. Bank of Taiwan Quarterly, 60(2), 154-186. 